OBITLIRI

\section{Nlity Binlins}

$\mathrm{M}$

any of us owe our love of Classics

Burns is the reason I am a Classics

teacher. She died last year and this is a

short tribute to her.

May taught at The Mary Erskine School, Edinburgh, the school which provided extras for The Prime of Miss Jean Brodie, and May herself was perennially in her prime, with her cultivated clipped Edinburgh tones keeping her pupils firmly in line. Her dedication to her subject was utterly infectious and her personality magnetic, her cry of "Right girls, books closed, jotters closed and hands up for the following questions!" riveting our attention from the start of the lesson. Miss Burns knew everything there was to know about the Romans and Greeks and imparted this to us with tremendous energy, zest and humour. She knew precisely the capabilities of each of her pupils, and to give less than you personally were capable of was to risk her beady-eyed displeasure. When she took us on trips, which she did far more often than other teachers, she drove the school minibus herself, at breakneck speed, and led her group up hills with the energy befitting the head of girls' CCF (which to my shame I avoided joining). In Italy she kept the predatory local youths at bay from her crocodile of entranced pupils with the instruction "Frosty faces, girls!"

We did not know at the time that May was at the forefront of the movement which revolutionised the teaching of Latin from its former dry-as-dust approach to the lively and modern subject it is today. She was a key member of a group of teachers commissioned by the Scottish Education Department in 1967 to write a new course more suited to modern requirements - a group which became the Scottish Classics Group, authors of Ecce Romani. The Group later worked with Longmans to produce the American edition of Ecce, and later authored a number of further works. They are probably best known south of the border for The Latin Language (sometimes known as "the Scottish book") and more recently for the excellent Introducing Cicero. Even at the time of her death May was still closely involved in the production of a new Latin course Let's Learn Latin, aimed mainly at adults and due to appear soon as course material for the Open University.

As a teacher I often wonder how I can live up to my responsibility to inspire my pupils with a love of learning. May did this for me by a belief in me personally, by never hesitating to demand more of me, and by her clear-sightedness and certainty - beyond any possibility of question - that Classics is the best subject in the world.

Catharine Jessop 